\title{
PENGARUH CURRENT RATIO DAN CASH RATIO TERHADAP RETURN ON ASSET PADA PT SUMBER ALFARIA TRIJAYA, TBK DI JAKARTA PERIODE TAHUN 2012-2019
}

\author{
${ }^{1 *}$ Firmanza, ${ }^{2}$ Khairil Fathir, ${ }^{3}$ Nardi, ${ }^{4}$ Muhammad Saddam \\ STIE Hidayatullah, Depok, Jawa Barat, Indonesia \\ *firmanza@stiehidayatullah.ac.id
}

\begin{abstract}
Abstrak
Penelitian ini bertujuan untuk mengetahui Pengaruh Current Ratio dan Cash Ratio Terhadap Return on Asset Pada PT. Sumber Alfaria Trijaya, Tbk di Jakarta. Metode yang digunakan adalah explanatory research. Teknik analisis menggunakan analisis statistik dengan pengujian regresi, korelasi, determinasi dan uji hipotesis. Hasil penelitian ini Current Ratio berpengaruh signifikan terhadap Return on Asset sebesar 52,8\%, uji hipotesis diperoleh $t$ hitung $>\mathrm{t}$ tabel atau $(2,592>2,447)$. Cash Ratio berpengaruh signifikan terhadap Return on Asset sebesar $38,4 \%$, uji hipotesis diperoleh $t$ hitung $>t$ tabel atau $(2,936>2,447)$. Current Ratio dan Cash Ratio secara simultan berpengaruh signifikan terhadap Return on Asset diperoleh persamaan regresi $Y=-4,258+0,113 X 1+0,067 X 2$ dan nilai determinasi sebesar 64,5\%, uji hipotesis diperoleh nilai $\mathrm{F}$ hitung $>\mathrm{F}$ tabel atau $(6,544>5,410)$.
\end{abstract}

Kata Kunci: Current Ratio, Cash Ratio, Return on Asset

Abstract

This study aims to determine the effect of the Current Ratio and Cash Ratio on Return on Assets at PT. Sumber Alfaria Trijaya, Tbk in Jakarta. The method used is explanatory research. The analysis technique uses statistical analysis with regression, correlation, determination and hypothesis testing. The results of this study that Current Ratio has a significant effect on Return on Assets by 52.8\%, hypothesis testing is obtained t count > t table or $(2,592>2.447)$. Cash Ratio has a significant effect on Return on Assets of 38.4\%, hypothesis testing is obtained $t$ count $>t$ table or $(2,936>2.447)$. Current Ratio and Cash Ratio simultaneously have a significant effect on Return on Assets obtained by the regression equation $Y=-4.258+0.113 X 1+0.067 X 2$ and the determination value is $64.5 \%$, hypothesis testing is obtained F count $>$ F table or $(6.544>5.410$. Keywords: Current Ratio, Cash Ratio, Return on Assets

\section{PENDAHULUAN}

Tak bisa dipungkiri jika perekonomian global masih belum menunjukkan tahap pemulihan, terutama dari tren negative komoditas termasuk minyak dunia serta lambatnya pemulihan perekonomian NegaraNegara Eropa, Jepang, Tiongkok dan Amerika masih menjadi penyebab tekanan ekonomi global yang berdampak pada perekonomian nasional. Dampak terhadap perekonomian dalam negeri dapat dilihat dari sektor investasi yang lesu dan biaya produksi yang semakin mahal disebabkan karena meningkatnya nilai tukar dollar terhadap rupiah.

Perlambatan ekonomi global memberikan dampak yang signifikan terhadap pertumbuhan dan kinerja perusahaan-perusahaan yang ada di dalam negeri, dimana ketidakpuasan ekonomi global juga dirasakan oleh salah satu perusahaan ritel terbesar di Indonesia yakni PT. Sumber Alfaria Trijaya, Tbk (Alfamart).
Ketidakpastian ekonomi global ini juga berdampak pada penurunan jumlah laba bersih yang diperoleh pada tahun 2015 yakni sebesar Rp. 464.304 (miliar) turun sebanyak Rp. 15.099 (miliar) jika dibandingkan dengan laba bersih tahun 2014 yakni sebesar Rp. 579.303 (miliar) sementara untuk tahun 2013 sebesar Rp. 559.630 (miliar) dan untuk tahun 2012 sebesar Rp. 526.077 (miliar). Ketidakpastian tersebut mengharuskan para pengusaha untuk lebih berhati-hati dalam mengeluarkan kebijakan dalam menjalankan setiap rencana yang dimiliki perusahaan dalam mencapai tujuan perusahaan. .

Tujuan setiap perusahaan berbedabeda. Skiner berpendapat dalam (Anoraga Panji, 2004)"Pada dasarnya yang menjadi tujuan utama setiap perusahaan adalah bagaimana menghasilkan laba secara maksimal, menjaga pertumbuhan dan kelangsungan hidup perusahaan". Ditengah perubahan kondisi ekonomi, perkembangan teknologi informasi dan persaingan usaha 
yang semakin cepat dan global, PT. Sumber Alfaria Trijaya, Tbk (Alfamart) tumbuh menjadi salah satu perusahaan yang terdepan dalam usaha ritel, dengan melayani lebih dari 4,2 juta pelanggan setiap harinya dilebih dari 13.745 gerai yang tersebar di Indonesia dan didukung lebih dari 90.000 karyawan. Kecepatan dan kecermatan beradaptasi serta strategi yang matang oleh perusahaan dalam melihat kondisi ekonomi menuntut manajemen perusahaan untuk melakukan perencanaan dan pengendalian kegiatan perusahaan di masa yang akan datang. Agar supaya perusahaan dapat mencapai tujuannya dengan baik maka perusahaan perlu untuk menilai sehat atau tidaknya kinerja perusahaan yang mereka jalankan.

Untuk menilai sehat atau tidaknya perusahaan tidak hanya dilihat dari gedung, pembangunan atau ekspansi. Faktor terpenting untuk menilai baik atau tidaknya perkembangan kondisi kinerja perusahaan terletak pada kinerja keuangan yang mereka miliki. Kinerja keuangan merupakan kegiatan pengelolaan sumber daya organisasi untuk mencapau tujuan organisasi. Kinerja keuangan PT. Sumber Alfarian Trijaya, Tbk (Alfamart) menunjukan tren yang baik dimana seperti yang telah dituliskan di paragraf sebelumnya bahwa laba bersih perusahaan pada tahun 2012 hingga 2014 selalu mengalami peningkatan sedangkan pada tahun 2015 laba bersih perusahaan harus mengalami penurunan. Jadi pada dasarnya, kinerja keuangan mempunyai tujuan untuk mengetahui seberapa jauh perkembangan perusahaan dari tahun ke tahun.

Untuk mengetahui tingkat pencapaian atau keberhasilan perusahaan dalam mencapai tujuannya, diperlukan indikatorindikator keuangan. Indikator-indikator keuangan tersebut dapat diperoleh dari laporan keuangan. Herry (2016:2) berpendapat bahwa "Laporan keuangan pada dasarnya adalah hasil dari proses akutansi yang dapat digunakan sebagai alat untuk mengkomunikasikan data keuangan atau aktivitas perusahaan kepada pihak-pihak yang berkepentingan". Melalui laporan keuangan PT. Sumber Alfaria Trijaya, Tbk (Alfamart), pihak-pihak yang berkepentingan mampu melihat bagaimana kondisi baik tidaknya atau sehat tidaknya kondisi kinerja keuangan perusahaan dan seberapa besar jumlah asset (kekayaan) , kewajiban (utang) dan modal (ekuitas) yang dimiliki perusahaan. Dengan kata lain, laporan keuangan ini berfungsi sebagai alat informasi yang menghubungkan perusahaan dengan pihak-pihak yang berkepentingan, yang menunjukkan kondisi kesehatan dan kinerja keuangan.

Menurut Irham Fahmi (2012:2), kinerja keuangan adalah suatu analisis yang dilakukan untuk melihat sejauh mana suatu perusahaan telah melaksanakan keuangan secara baik dan benar. Sedangkan menurut Jumingan ( 2011:239) kinerja keuangan merupakan gambaran kondisi keuangan pada suatu periode tertentu baik menyangkut aspek penghimpunan dana maupum penyaluran dana yang biasanya diukur dengan indikator kecukupan modal, likuiditas dan profitabilitas. Berdasarkan pengertian dari berbagai sumber diatas, yang dimaksud dengan kinerja keuangan adalah suatu analisis yang dilakukan untuk melihat sejauh mana suatu perusahaan telah melakukan keuangan secara baik dan benar terhadap keuangan melalui review data, menghitung, mengukur, menginterpretasi dan memberikan solusi terhadap keuangan perusahaan.

Untuk mengetahui posisi kinerja keuangan PT. Sumber Alfaria Trijaya, Tbk) Alfamart) serta hasil-hasil yang telah dicapai oleh perusahaan, perlu adanya analisis terhadap laporan kinerja keuangan dari perusahaan tersebut. Untuk mengukur tingkat kesehatan kinerja keuangan, suatu perusahaan dapat menggunakan rasio keuangan. Dalam bukunya "Analisis laporan keuangan " Herry (2016:138) mengemukakan bahwa "Rasio keuangan merupakan angka yang diperoleh dari suatu pos laporan keuangan dengan pos lainnya yang mempunyai hubungan yang relevan dan signifikan. Rasio keuangan ini pada dasarnya hanya menyederhanakan informasi yang menggambarkan hubungan antara pos tertentu dengan pos lainnya". Dengan penyederhanaan ini kita dapat menilai secara cepat hubungan antara pos dan dapat membandingkannya dengan rasii lain sehingga kita dapat memperoleh informasi dan memberikan penilaian mengenai kondisi kinerja keuangan perusahaan. 
Dalam analisis kinerja keuangan, suatu perusahaam dapat mengukur dengan perhitungan rasio seperti rasio likuiditas dan prifitabilitas. "Menurut Kasmir (2017:129), rasio likuiditas merupakan analisis keuangan yang berkaitan dengan kemampuan perusahaan untuk membayar utang atau kewajibannya. Sedangkan rasio profitabilitas

Tabel 1. Hasil Penelitian dan Perhitungan Rasio-Rasio Keuangan

PT. Sumber Alfaria Trijaya, Tbk Tahun 2012-2019

\begin{tabular}{|c|c|c|c|c|}
\hline \multirow{2}{*}{ Tahun } & \multicolumn{2}{|c|}{ Profitabilitas } & \multicolumn{2}{c|}{ Likuiditas } \\
\cline { 2 - 5 } & ROA & ROE & Current Ratio & Cash Ratio \\
\hline 2012 & $6,001 \%$ & $23,57 \%$ & $78,00 \%$ & $1,566 \%$ \\
\hline 2013 & $5,886 \%$ & $1421,06 \%$ & $84,48 \%$ & $20,90 \%$ \\
\hline 2014 & $5,378 \%$ & $14,78 \%$ & $97,57 \%$ & $23,09 \%$ \\
\hline 2015 & $5,190 \%$ & $21,85 \%$ & $82,06 \%$ & $8,664 \%$ \\
\hline 2016 & $4,092 \%$ & $19,03 \%$ & $91,45 \%$ & $6,068 \%$ \\
\hline 2017 & $3,054 \%$ & $9,570 \%$ & $110,17 \%$ & $10,88 \%$ \\
\hline 2018 & $2,728 \%$ & $10,46 \%$ & $89,60 \%$ & $8,201 \%$ \\
\hline 2019 & $1,176 \%$ & $4,909 \%$ & $88,42 \%$ & $7,251 \%$ \\
\hline Jumlah & $27,504 \%$ & $125,229 \%$ & $721,75 \%$ & 86,62 \\
\hline
\end{tabular}

Sumber: Data yang diolah, 2020

Berdasarkan tabel diatas, dapat diliat trend terjadi pada pergerakkan ROA dari tahun 2012 sampai tahun 2019 terjadi penurunan yang fluktuatif begitu pula pada ROE dari tahun 2012 sampai 2019 terjadi penurunan yang fluktuatif, pergerakan Current Ratio terjadi kenaikan dari tahun 2012 sampai tahun 2017 kemudian tahun 2018 dan 2019 terjadi penurunan yang signifikan, pergerakan Cash Ratio terjadi kenaikan yang signifikan dari tahun 2012 sampai 2014 kemudian pada tahun 2015 sampai 2018 terjadi penurunan yang fluktuatif.

Berdasarkan tabel diatas, dapat pula dilihat bahwa terjadi pergerakkan yang menurun pada ROA, ROE, Current Ratio, dan Cash Ratio. Hal tersebut juga akan berdampak pada pergerakan laba pada PT. Sumber Alfaria Trijaya, Tbk (Alfamart).

Aset yang besar seharusnya mengindikasikan pendapatan yang besar jika aset-aset yang dimiliki oleh PT. Sumber Alfaria Trijaya, Tbk (Alfamart) digunakan secara optimal. Kesenjangan yang semakin lebar antara laba dan aset akan memperkecil tingkat profitabilitas.

Berdasarkan uraian-uraian sebelumnya, peneliti tertarik untuk mengadakan penelitian dengan judul "Pengaruh Current Ratio dan Cash Ratio dengan total utang lancar". menurut Kasmir (2017:196), merupakan rasio untuk menilai kemampuan perusahaan dalam mencari keuntungan. Oleh karena itu kinerja keuangan pada suatu perusahaan sangatlah penting, maka diperlukan analisis laporan keuangan yang tepat, akurat, dan terpercaya.
Terhadap Return on Asset pada PT. Sumber Alfaria Trijaya, Tbk di Jakarta".

\section{TINJAUAN PUSTAKA}

\section{Current Ratio}

Rasio Lancar (Current Ratio) menurut Van Home (2009:206) adalah "Rasio lancar menunjukkan kemampuan perusahaan untuk membayar kewajiban jangka pendneknya menggunakan aktiva lancar".

\section{Cash Ratio}

Rasio Kas (Cash Ratio) menurut Kasmir (2008:62), rasio kas adalah "Rasio yang merupakan perbandingan antara kas yang ada di perusahaan dibandingkan

\section{Return on Asset}

Rasio Profitabilitas yaitu rasio yang digunakan untuk mengukur seberapa besar kemampuan perusahaan memperoleh laba baik dengan hubungan penjualan maupun laba rugi modal sendiri.

\section{METODE PENELITIAN}

\section{Populasi}

Populasi dalam penelitian ini berdasar laporan keuangan selama 8 tahun PT. Sumber Alfaria Trijaya, Tbk di 
Jakarta

\section{Sampel}

Teknik pengambilan sampling dalam penelitian ini adalah samplel jenuh, dimana semua anggota populasi dijadikan sebagai sampel. Dengan demikian sampel dalam penelitian ini laporan keuangan selama 8 tahun.

\section{Jenis Penelitian}

Jenis penelitian yang dipakai adalah asosiatif, dimana tujuannya adalah untuk mengetahui mencari keterhubungan antar variabel independen terhadap variabel dependen

\section{Metode Analisis Data}

Dalam menganalisis data digunakan uji asumsi klasik, regresi, koefisien korelasi, koefisien determinasi dan uji hipotesis baik parsial maupun simultan.

\section{HASIL PENELITIAN}

\section{Analisis Deskriptif}

Pada pengujian ini digunakan untuk mengetahui besarnya persentase minimum dan maksimum, persentase rata-rata dan standar deviasi dari masingmasing variabel. Adapun hasilnya sebagai berikut:

Tabel 2. Hasil Analisis Descriptive Statistics

\section{Descriptive Statistics}

\begin{tabular}{l|r|r|r|r|r} 
& N & Minimum & Maximum & Mean & Std. Deviation \\
\hline Current Ratio (X1) & 8 & 4.9 & 84.5 & 30.384 & 31.8893 \\
\hline Cash Ratio (X2) & 8 & 15.7 & 110.2 & 74.479 & 35.6689 \\
\hline Return on Asset (Y) & 8 & 1.2 & 6.0 & 4.188 & 1.7357 \\
\hline Valid N (listwise) & 8 & & & & \\
\hline
\end{tabular}

Current Ratio diperoleh nilai persentase minimum sebesar $4,9 \%$ dan nilai persentase maximum $84,5 \%$ dengan rata-rata sebesar $30,38 \%$ dengan standar deviasi 31,88\%.

Cash Ratio diperoleh nilai persentase minimum sebesar $15,7 \%$ dan nilai persentase maximum $110,2 \%$ dengan nilai rata-rata sebesar $74,47 \%$ dengan standar deviasi 35,66\%.

Return on Asset diperoleh nilai persentase minimum sebesar $1,2 \%$ dan nilai persentase maximum $6,0 \%$ dengan rata-rata sebesar $1,73 \%$ dengan standar deviasi 3,499\%.

\section{Analisis Kuantitatif}

Pada analisis ini dimaksudkan untuk mengetahui pengaruh variabel independen terhadap variabel dependen. Adapun hasil pengujian sebagai berikut:

\section{a. Analisis Regresi Linier Berganda}

Uji regresi ini dimaksudkan untuk mengetahui perubahan variabel dependen jika variabel independen mengalami perubahan. Adapun hasil pengujiannya sebagai berikut:

Tabel 3. Hasil Pengujian Regresi Liner Berganda

Coefficients $^{\mathbf{a}}$

Unstandardized Coefficients

\begin{tabular}{|c|c|c|c|c|c|}
\hline Model & B & Std. Error & Beta & $\mathrm{t}$ & Sig. \\
\hline 1 (Constant) & -4.258 & 5.680 & & -.750 & .487 \\
\hline Current Ratio (X1) & .113 & .059 & 2.070 & 1.916 & .113 \\
\hline Cash Ratio (X2) & .067 & .053 & 1.386 & 1.283 & .256 \\
\hline
\end{tabular}

a. Dependent Variable: Return on Asset (Y)

Berdasarkan hasil pengujian pada tabel di atas, diperoleh persamaan regresi $Y=-4,258+0,113 X 1+0,067 X 2$. Dari persamaan tersebut dijelaskan sebagai berikut:

1) Konstanta sebesar $-4,258$ diartikan jika Current Ratio dan Cash Ratio tidak ada, maka telah terdapat nilai
Return on Asset sebesar -4,258 point.

2) Koefisien regresi Current Ratio sebesar 0,113, angka ini positif artinya setiap ada peningkatan Current Ratio sebesar 0,113 maka Return on Asset juga akan mengalami peningkatan sebesar 
0,113 point.

3) Koefisien regresi Cash Ratio sebesar 0,067, angka ini positif artinya setiap ada peningkatan Cash Ratio sebesar 0,067 maka Return on Asset juga akan mengalami peningkatan sebesar 0,067 point.

Tabel 4. Hasil Pengujian Koefisien Korelasi Cur
Correlations $^{\mathbf{b}}$ b. Analisis Koefisien Korelasi

Analisis koefisien korelasi dimaksudkan untuk mengetahui tingkt kekuatan hubungan dari variabel independen terhadap variabel dependen baik secara parsial maupun simultan. Adapun hasil pengujian sebagai berikut:

\begin{tabular}{ll|r|r} 
& & $\begin{array}{c}\text { Current Ratio } \\
\text { (X1) }\end{array}$ & $\begin{array}{r}\text { Return on Asset } \\
(Y)\end{array}$ \\
\hline Current Ratio (X1) & Pearson Correlation & 1 & $.727^{*}$ \\
\cline { 2 - 4 } & Sig. (2-tailed) & & .041 \\
\hline Return on Asset (Y) & Pearson Correlation & $.727^{*}$ & 1 \\
\cline { 2 - 4 } & Sig. (2-tailed) & .041 & \\
\hline
\end{tabular}

*. Correlation is significant at the 0.05 level (2-tailed).

b. Listwise $\mathrm{N}=8$

Berdasarkan hasil pengujian diperoleh nilai korelasi sebesar 0,727 artinya Current Ratio memiliki hubungan yang kuat terhadap Return on Asset.

Tabel 5. Hasil Pengujian Koefisien Korelasi Cash Ratio Terhadap Return on Asset. Correlations ${ }^{\mathrm{a}}$

\begin{tabular}{|c|c|c|c|}
\hline & & Cash Ratio (X2) & $\begin{array}{c}\text { Return on } \\
\text { Asset (Y) }\end{array}$ \\
\hline \multirow[t]{2}{*}{ Cash Ratio (X2) } & Pearson Correlation & 1 & -.620 \\
\hline & Sig. (2-tailed) & & .101 \\
\hline \multirow[t]{2}{*}{ Return on Asset (Y) } & Pearson Correlation & -.620 & 1 \\
\hline & Sig. (2-tailed) & .101 & \\
\hline
\end{tabular}

a. Listwise $\mathrm{N}=8$

Berdasarkan hasil pengujian diperoleh nilai korelasi sebesar $-0,620$ artinya Cash Ratio memiliki hubungan yang NEGATIF kuat terhadap Return on Asset.

Tabel 6. Hasil Pengujian Koefisien Korelasi Current Ratio dan Cash Ratio secara simultan Terhadap Return on Asset.

\section{Model Summary}

\begin{tabular}{|c|c|c|c|c|}
\hline Model & $\mathrm{R}$ & R Square & $\begin{array}{l}\text { Adjusted R } \\
\text { Square }\end{array}$ & $\begin{array}{l}\text { Std. Error of the } \\
\text { Estimate }\end{array}$ \\
\hline 1 & $.803^{a}$ & .645 & .503 & 1.2235 \\
\hline
\end{tabular}

Berdasarkan hasil pengujian diperoleh nilai korelasi sebesar 0,803 artinya Current Ratio dan Cash Ratio secara simultan memiliki hubungan yang sangat kuat terhadap Return on Asset.

\section{c. Analisis Koefisien Determinasi}

Analisis koefisien determinasi dimaksudkan untuk mengetahui besarnya persentase pengaruh dari variabel independen terhadap variabel dependen baik secara parsial maupun simultan. Adapun hasil pengujian sebagai berikut: 
Tabel 7. Hasil Pengujian Koefisien Determinasi Current Ratio Terhadap Return on Asset. Model Summary

\begin{tabular}{lrr|rr|r} 
Model & & \multicolumn{2}{|c|}{$\begin{array}{c}\text { Adjusted R } \\
\text { Square }\end{array}$} & $\begin{array}{c}\text { Std. Error of the } \\
\text { Estimate }\end{array}$ \\
\hline 1 & & R Square & .450 & 1.2877 \\
\hline
\end{tabular}

a. Predictors: (Constant), Current Ratio (X1)

Berdasarkan hasil pengujian

kontribusi pengaruh sebesar 52,8\% diperoleh nilai determinasi sebesar 0,528 artinya Current Ratio memiliki terhadap Return on Asset.

Tabel 8. Hasil Pengujian Koefisien Determinasi Cash Ratio Terhadap Return on Asset. Model Summary

\begin{tabular}{lr|r|rr|r} 
Model & & \multicolumn{2}{c|}{$\begin{array}{c}\text { Adjusted R } \\
\text { Square }\end{array}$} & $\begin{array}{c}\text { Std. Error of the } \\
\text { Estimate }\end{array}$ \\
\hline 1 & & R Square & \multicolumn{2}{c}{ Squar } & 1.4709 \\
\hline
\end{tabular}

a. Predictors: (Constant), Cash Ratio (X2)

Berdasarkan hasil pengujian diperoleh nilai determinasi sebesar 0,384 artinya Cash Ratio memiliki kontribusi pengaruh sebesar 38,4\% Tabel 9. Hasil Pengujian Koefisien Determinasi Current Ratio dan Cash Ratio Terhadap Return on Asset.

Model Summary

\begin{tabular}{lrr|rr|c} 
Model & R & R Square & $\begin{array}{c}\text { Adjusted R } \\
\text { Square }\end{array}$ & $\begin{array}{c}\text { Std. Error of the } \\
\text { Estimate }\end{array}$ \\
\hline 1 & $.803^{\mathrm{a}}$ & .645 & .503 & 1.2235 \\
\hline
\end{tabular}

a. Predictors: (Constant), Cash Ratio (X2), Current Ratio (X1)

Berdasarkan hasil pengujian diperoleh nilai determinasi sebesar 0,645 artinya Current Ratio dan Cash Ratio secara simultan memiliki kontribusi pengaruh sebesar 64,5\% terhadap Return on Asset, sedangkan sisanya sebesar $35,5 \%$ dipengaruhi faktor lain.

\section{d. Uji Hipotesis}

\section{Uji hipotesis Parsial (Uji t)}

Pengujian hipotesis dengan uji $t$ digunakan untuk mengetahui hipotesis

Tabel 10. Hasil Uji Hipotesis Current Ratio Terhadap Return on Asset.

\begin{tabular}{|c|c|c|c|c|c|c|}
\hline \multirow{3}{*}{\multicolumn{2}{|c|}{ Model }} & \multicolumn{3}{|c|}{ Coefficients $^{a}$} & \multirow[b]{3}{*}{$\mathrm{t}$} & \multirow[b]{3}{*}{ Sig. } \\
\hline & & \multicolumn{2}{|c|}{$\begin{array}{l}\text { Unstandardized } \\
\text { Coefficients }\end{array}$} & \multirow{2}{*}{$\begin{array}{c}\text { Standardized } \\
\text { Coefficients } \\
\text { Beta } \\
\end{array}$} & & \\
\hline & & $\mathrm{B}$ & Std. Error & & & \\
\hline 1 & (Constant) & 2.986 & .650 & & 4.595 & .004 \\
\hline & $\begin{array}{l}\text { Current Ratio } \\
\text { (X1) }\end{array}$ & .040 & .015 & .727 & 2.592 & .041 \\
\hline
\end{tabular}

a. Dependent Variable: Return on Asset (Y)

Berdasarkan hasil pengujian pada tabel di atas, diperoleh nilai $\mathrm{t}$ hitung $>\mathrm{t}$ tabel atau $(2,592>2,447)$, parsial mana yang diterima. Pengujian juga dapat dilakukan dengan menggunakan membandingkan nilai signifikansi dengan Sig.0,05. Adapun hasil pengujiannya sebagai berikut:

Hipotesis Pertama: Terdapat pengaruh yang signifikan antara Current Ratio terhadap Return on Asset.

Hipotesis Kedua: Terdapat pengaruh yang signifikan antara Cash Ratio terhadap Return on Asset. 
Tabel 11. Hasil Uji Hipotesis Cash Ratio Terhadap Return on Asset.

Coefficients ${ }^{a}$

Unstandardized $\quad$ Standardized

Coefficients Coefficients

\begin{tabular}{|c|c|c|c|c|c|c|}
\hline \multirow{2}{*}{\multicolumn{2}{|c|}{ Model }} & \multicolumn{2}{|c|}{ Coefficients } & \multirow{2}{*}{$\begin{array}{c}\text { Coefficients } \\
\text { Beta }\end{array}$} & \multirow[b]{2}{*}{ t } & \multirow[b]{2}{*}{ Sig. } \\
\hline & & $\mathrm{B}$ & Std. Error & & & \\
\hline 1 & (Constant) & 6.435 & 1.272 & & 5.059 & .002 \\
\hline & Cash Ratio (X2) & .030 & .016 & 1.620 & 2.936 & .010 \\
\hline
\end{tabular}

a. Dependent Variable: Return on Asset (Y)

Berdasarkan hasil pengujian pada tabel di atas, diperoleh nilai $\mathrm{t}$ hitung $>\mathrm{t}$ tabel atau $(2,936>2,447)$, dengan demikian terdapat pengaruh yang signifikan antara Cash Ratio terhadap Return on Asset.

\section{Uji Hipotesis Simultan (Uji F)}

Pengujian hipotesis dengan uji $\mathrm{F}$ digunakan untuk mengetahui hipotesis

Tabel 12. Hasil Uji Hipotesis Current Ratio dan Cash Ratio Terhadap Return on Asset.

ANOVAa

\begin{tabular}{ll|r|r|r|r|r} 
Model & & Sum of Squares & df & Mean Square & F & Sig. \\
\hline \multirow{2}{*}{1} & Regression & 13.604 & 2 & 6.802 & 6.544 & $.045^{\mathrm{b}}$ \\
\cline { 2 - 7 } & Residual & 7.485 & 5 & 1.497 & & \\
\cline { 2 - 7 } & Total & 21.089 & 7 & & & \\
\hline
\end{tabular}

Berdasarkan hasil pengujian pada tabel di atas, diperoleh nilai $\mathrm{F}$ hitung $>\mathrm{F}$ tabel atau $(6,544>5,410)$, dengan demikian terdapat pengaruh yang signifikan antara Current Ratio dan Cash Ratio terhadap Return on Asset.

\section{PEMBAHASAN HASIL PENELITIAN}

1. Pengaruh Current Ratio Terhadap Return on Asset

Current Ratio berpengaruh signifikan terhadap Return on Asset dengan korelasi sebesar 0,727 atau memiliki hubungan yang kuat dengan kontribusi pengaruh sebesar 52,8\%. Pengujian hipotesis diperoleh nilai $t$ hitung $>\mathrm{t}$ tabel atau $(2,592>2,447)$. Dengan demikian terdapat pengaruh signifikan antara Current Ratio terhadap Return on Asset.

\section{Pengaruh Cash Ratio Terhadap Return on Asset}

Cash Ratio berpengaruh signifikan terhadap Return on Asset dengan korelasi sebesar -0,620 atau memiliki hubungan yang kuat dengan kontribusi pengaruh simultan yang mana yang diterima. Pengujian juga dapat dilakukan dengan menggunakan membandingkan nilai signifikansi dengan Sig.0,05. Adapun hasil pengujiannya sebagai berikut:

Hipotesis Ketiga: Terdapat pengaruh yang signifikan antara Current Ratio dan Cash Ratio terhadap Return on Asset. sebesar 38,4\%. Pengujian hipotesis diperoleh nilai $\mathrm{t}$ hitung $>\mathrm{t}$ tabel atau $(2,936>2,447)$. Dengan demikian terdapat pengaruh signifikan antara Cash Ratio terhadap Return on Asset.

\section{Pengaruh Current Ratio dan Cash Ratio} Terhadap Return on Asset

Current Ratio dan Cash Ratio berpengaruh signifikan terhadap Return on Asset dengan diperoleh persamaan regresi $Y=-4,258+0,113 X 1+0,067 \mathrm{X} 2$, nilai korelasi sebesar 0,803 atau memiliki hubungan yang sangat kuat dengan kontribusi pengaruh sebesar 64,5\% sedangkan sisanya sebesar $35,5 \%$ dipengaruhi faktor lain. Pengujian hipotesis diperoleh nilai $\mathrm{F}$ hitung $>\mathrm{F}$ tabel atau $(6,544>5,410)$. Dengan demikian terdapat pengaruh signifikan antara Current Ratio dan Cash Ratio terhadap Return on Asset.

\section{KESIMPULAN DAN SARAN}

\section{Kesimpulan}

Berdasarkan hasil perhitungan dan pembahasan di atas, maka disimpulkan sebagai berikut: 
a. Current Ratio berpengaruh signifikan terhadap Return on Asset dengan kontribusi pengaruh sebesar $52,8 \%$. Uji hipotesis diperoleh nilai $\mathrm{t}$ hitung $>\mathrm{t}$ tabel atau $(2,592>2,447)$.

b. Cash Ratio berpengaruh signifikan terhadap Return on Asset dengan kontribusi pengaruh sebesar 38,4\%. Uji hipotesis diperoleh nilai t hitung $>\mathrm{t}$ tabel atau $(2,936>2,447)$.

c. Current Ratio dan Cash Ratio berpengaruh signifikan terhadap Return on Asset dengan kontribusi pengaruh sebesar $64,5 \%$ sedangkan sisanya sebesar $35,5 \%$ dipengaruhi faktor lain. Uji hipotesis diperoleh nilai $\mathrm{F}$ hitung $>\mathrm{F}$ tabel atau $(6,544>5,410)$.

\section{Saran}

Berdasarkan hasil kesimpulan yang sudah dipaparkan di atas, maka penulis memberikan saran sebagai berikut:

a. Perusahaan harus memperbesar aktiva lancarnya guna memastikan kecukupan untuk pembayaran hutang jangka pendeknya.

b. Perusahaan harus selalu memperhatikan kemampuan membayar dengan selalu mengacu pada inventory liquid atau tidaknya.

c. Perusahaan harus selalu melakukan suatu analisis yang dilakukan untuk melihat sejauh mana suatu perusahaan telah melaksanakan dengan menggunakan aturan-aturan pelaksanaan keuangan secara baik dan benar.

\section{DAFTAR PUSTAKA}

Agus Harjito dan Martono, "Manajemen Keuangan", Penerbit Ekonusa. Yogyakarta, 2007.

Agus Sartono, "Manajemen Keuangan Toeri dan Aplikasi", Edisi keempat, Penerbit BPFE-Yogyakarta,2010.

Algifari. (2015). "Analisis Regresi untuk Bisnis dan Ekonomi”. Yogyakarta: BPFE.

Algifari. (2015). "Analisis Regresi untuk Bisnis dan Ekonomi". Yogyakarta: BPFE.

Arikunto, Suharsimi (2014). "Prosedur Penelitian Suatu Pendekatan Praktek". Jakarta: Rineka Cipta.

Arikunto, Suharsimi (2014). "Prosedur Penelitian Suatu Pendekatan Praktek".
Jakarta: Rineka Cipta.

Bambang Riyanto, "Dasar-Dasar Pembelanjaan Perusahaan", Edisi keempat, Cetakan Ketujuh, Penerbit BPFE, Yogyakarta, 2001

Haque, M. G., et al. (2021). Micro Financial Sharia Non-bank Strategic Analysis: a Study at BMT Beringharjo, Yogyakarta. Budapest International Research and Critics Institute (BIRCI-Journal): Humanities and Social Sciences, 4(2), 1677-1686.

Imam Ghozali (2017). "Aplikasi Analisis Multivariate Dengan Program SPSS". Edisi Kelima. Semarang: Badan Penerbit Undip.

Imam Ghozali (2017). "Aplikasi Analisis Multivariate Dengan Program SPSS". Edisi Kelima. Semarang: Badan Penerbit Undip.

Istijanto (2014) "Riset Sumber Daya Manusia". Jakarta: PT. Gramedia Pustaka

Istijanto (2014) "Riset Sumber Daya Manusia”. Jakarta: PT. Gramedia Pustaka

Kharis, Ismu Fadli (2011). "Studi Mengenai Impulse Buying dalam Penjualan Online". Semarang : Skripsi Universitas Diponegoro

Kharis, Ismu Fadli (2011). "Studi Mengenai Impulse Buying dalam Penjualan Online". Semarang : Skripsi Universitas Diponegoro

Martono dan Agus Harjito, "Manajemen Keuangan", Penerbit Ekonisia, Yogyakarta, 2007.

Pujiati, H., et al. (2021). Effect of ISO 9001: 2015 Quality Management Implementation in Education on School Performance. Journal of Contemporary Issues in Business and Government, 27(1), 1848-1855.

Putra, IGS., (2021). The Effect Of MacroEconomic Indicators On Share Prices In The Construction Sub-Sector And Building Companies Listed In Indonesia Stock Exchange 2013-2018. Turkish Journal of Computer and Mathematics Education (TURCOMAT). 12(9) 107-113

Rao, Purba, (2012). "Measuring Consumer Perceptions Through Factor Analysis", The Asian.

Riyanto dan Bambang, "Dasar-Dasar Pembelanjaan Perusahaan”, BPFE, Yogyakarta, 2008. 
Safri M. Sofyan Harahap, "Budgeting, Penganggaran Perencanaan Lengkap", Cetakan Kedua, PT. Pustaka Quantum, Jakarta, 2010.

Santoso, Singgih (2015). "Menguasai Statistik Multivariat". Jakarta: PT Elex Media Komputindo.

Santoso, Singgih (2015). "Menguasai Statistik Multivariat". Jakarta: PT Elex Media Komputindo.

Sartono, "Manajemen Keuangan Aplikasi Dan Teori", Edisi Keempat, BPFE, Yogyakarta, 2008.

Sawir, "Analisis Kinerja Keuangan dan Perencanaan Keuangan Perusahaan", Cetakan ketiga, Penerbit PT. Gramedia Pustaka Utama, Jakarta, 2003.
Sudjana (2014) “Metode Statistika”, Bandung: Tarsido.

Sugiyono (2017), "Metode Penelitian Administrasi : dilengkapi dengan Metode $R \& D$ ". Bandung: Alfabeta.

Sugiyono (2017), "Metode Penelitian Administrasi : dilengkapi dengan Metode $R \& D^{\prime \prime}$. Bandung: Alfabeta.

Suhartono, A., et al. (2019). Pengaruh Earning Per Share Dan Return On Asset Terhadap Harga Saham Pada PT. Bank Negara Indonesia Tbk Periode 20092018. Jurnal Manajemen, Bisnis dan Organisasi (JUMBO), 3(3), 182-194.

Sutrisno. 2008. Manajemen Keuangan Teori Konsep dam Aplikasi. Yogyakarta: Ekonosia. 